\title{
THE RELEVANCE OF REMORSE IN SENTENCING: A REPLY TO BAGARIC AND AMARASEKARA (AND DUFF)
}

\section{STEVEN TUdOR*}

\begin{abstract}
[In their 2001 article "Feeling Sorry? — Tell Someone Who Cares: The Irrelevance of Remorse in Sentencing", Bagaric and Amarasekara argue that offender remorse should be abandoned as a mitigating factor in sentencing because it lacks adequate doctrinal support. The present article argues that Bagaric and Amarasekara's survey of reasons for remorse being a mitigating factor is not wide enough, and, moreover, that their arguments against the reasons that they do consider are, at least, controversial. In the course of this reply, the present article also replies to arguments against remorse as a mitigating factor put forward by $R$. A. Duff.]
\end{abstract}

\section{INTRODUCTION}

In Feeling Sorry? - Tell Someone Who Cares: The Irrelevance of Remorse in Sentencing, Bagaric and Amarasekara argue that "there is no justifiable doctrinal basis for according a sentencing discount to offenders who evince regret for what they have done". ${ }^{1}$ That remorse may be treated as a mitigating factor in sentencing is, as the authors note, a settled principle in sentencing law in many jurisdictions. In Bagaric and Amarasekara's view, however, this common legal principle is in fact merely an "intuition" or "feeling" that lacks adequate theoretical support. They survey a number of possible supports for this "intuition", arguing that each in turn fails to provide the proffered justification. From this they conclude that no theoreti-

${ }^{*}$ Lecturer, School of Law, La Trobe University.

${ }^{1}$ Mirko Bagaric \& Kumar Amarasekara, Feeling Sorry? - Tell Someone Who Cares: The Irrelevance of Remorse in Sentencing, 40 HOWARD J. OF CRIMINAL JUSTICE 364, 364 (2001). 
cal support can in fact be found for it, and that therefore "remorse should henceforth be abandoned as a sentencing consideration”. ${ }^{2}$ (It is not clear whether they see such abandonment taking the form of an explicit legal prohibition on judges taking remorse into account, or whether they envisage judges, in their discretion, no longer feeling a call to do so.)

The present article is a critical reply to Bagaric and Amarasekara. It seeks to defend the idea that remorse may be treated as a mitigating factor in sentencing by countering Bagaric and Amarasekara's criticisms. (For ease of reference I shall henceforth refer to the idea that remorse may be treated as a mitigating factor in sentencing as "the remorse principle". I shall not here be concerned with defending the stronger views that remorse must always mitigate sentence or ought normally to do so.) I shall proceed by critically examining Bagaric and Amarasekara's main points against the remorse principle, in the order in which they present them. (I shall not, however, address other important matters that they discuss, such as the practical difficulties in distinguishing genuine remorse from feigned remorse or from distinct experiences such as self-pity. The discussion here shall assume cases of genuine remorse.) In the course of replying to Bagaric and Amarasekara, I shall also reply to some arguments against the remorse principle presented by R. A. Duff, who is one of the subjects of Bagaric and Amarasekara's criticism even though he himself agrees that remorse should not mitigate sentence. ${ }^{3}$

With regard to definitional preliminaries, Bagaric and Amarasekara take it that remorse is "the feeling of regret or sorrow for what one has done". ${ }^{4}$ While this is not wrong, it does, in my view, need supplementing. Of course, any definition of "remorse" will be more or less contentious; the term is used with some latitude in ordinary language, and is not subject to a standard definition in law, psychology or philosophy. ${ }^{5}$ Nevertheless, as an enabling assumption of the present paper, I shall hazard a definition by proposing that remorse is an experience involving a particular complex of dynamically interrelated elements of feeling, understanding, desire and will. ${ }^{6}$ More specifically, it involves the kind of suffering felt by someone who acknowledges a wrong they have done to another person, who regrets doing it and wishes that they had not done it, who now desires somehow to repair the harm done and somehow to redeem themself, and who at some stage actually wills to action in some way in relation to that end (whether ultimately "successfully" or not). This complex experience, moreover, takes place over a period of time and is not a passing sensation.

\footnotetext{
${ }^{2}$ Id., at 375.

${ }^{3}$ R. A. DufF, Punishment, COMmunication, AND COMMUNity 118-21 (2001).

${ }^{4}$ Bagaric \& Amarasekara, supra note 1, at 364.

${ }^{5}$ Michael Proeve et al., Mitigation Without Definition: Remorse in the Criminal Justice System, 31 AUSTRALIAN N.Z.J.C 16, 17-18 (1999).

${ }^{6}$ I draw here upon STEVEN TUDOR, COMPASSION AND REMORSE: ACKNOWLEDGING THE SUFFERING OTHER chs 6-8 (2001) and Justin OAKLey, MORALiTy AND tHE EMOTIONS 6 (1992). See also RAIMOND GAITA, GOOD AND EVIL: AN ABSOLUTE CONCEPTION, ch 4 (2d ed. 2004).
} 


\section{NO REWARD FOR DOING WHAT IS EXPECTED?}

The first and most interesting of Bagaric and Amarasekara's arguments is that since (i) remorse is what an offender ought to feel, and (ii) one should not be rewarded simply for doing what one ought to do, therefore (iii) an offender should not be rewarded simply for feeling remorse. ${ }^{7}$ Let us examine the second premise first. "[R]ewards," say Bagaric and Amarasekara, "are not handed out for merely doing what is expected - only for clearly going beyond one's moral and/or legal obligations". ${ }^{8}$ (I shall take it that by an "expected" action or response, Bagaric and Amarasekara mean an action or response that one ought to do or is required or obligated to do rather than one that is predicted to occur - though, of course, an action may be both.) Bagaric and Amarasekara find it "curious" that criminals are treated differently to surgeons, police officers and plumbers who do what is expected of them and do not get rewarded. They assert that " $[\mathrm{t}]$ he only possible rationale for this is the perverse logic that the more rotten one is the less we can expect of them"9 so that, presumably, we do not expect the "rotten" offender to experience remorse and thus may properly reward them when they do. Bagaric and Amarasekara oppose such a policy, saying that, in fact, "[t]he more of a scoundrel one has become, the more that can rightly be expected of him or her in order to claw his or her way back into the community”. ${ }^{10}$

It should be conceded that there are indeed limitations to the idea that a "reward" is an appropriate response to an offender's remorse. However, Bagaric and Amarasekara have not quite captured that sense of inadequacy. First of all, they do not explain the sense of "reward" that they use. They seem, however, to be working with what we might call a conception of reward as a deserved or merited benefit, in contrast with a more behaviourist and less moral conception of reward that sees it simply as a benefit to induce a particular action. If so, then it would appear to be simply not true that we only give desert rewards for doing more than is required. For example, the school student who is (normatively) "expected" to pass their exams and does so may nevertheless be rewarded by their parents for passing. This type of reward is the congratulatory type of reward, one which recognises a valuable (even if required or predicted) achievement and congratulates the person for it. Thus it is not the case that the "perverse logic" Bagaric and Amarasekara identify is the only possible rationale for rewarding remorse. The reward may well be a kind of congratulation or — indeed, better — recognition or acknowledgment.

In any case, surgeons, police and plumbers typically are rewarded for what they do - they are doing a job they are already paid to do or that they expect to get paid for. Thus, their desert-reward is based on their earning it. They are not, though, it is true, rewarded for doing what is expected of them. Rather what is expected of them is so expected because they have been or will be paid for what they do. To reward fulfilling that sort of expectation would indeed be odd; it would be double-payment.

\footnotetext{
${ }^{7}$ Bagaric \& Amarasekara, supra note 1, at 364.

${ }^{8}$ Id.

${ }^{9} \mathrm{Id}$.

${ }^{10}$ Id., at $364-5$.
} 
A parallel does not arise in the case of criminal offenders, for the expectations of them are of a different kind (unless one subscribes to the view that offending is an obtaining of advantage without due payment). It is not, therefore, prima facie odd that criminals should be treated differently in this respect.

When Bagaric and Amarasekara propose that more is expected of the greater scoundrel, what kind of expectation is in view? It would seem that in this context this is to be cashed out in terms of a greater degree or depth of remorse being expected of the greater scoundrel. This seems uncontroversial so far as it goes, but it is not clear why that in itself should make rewarding the achievement of that deeper remorse inappropriate with a reduction of sentence.

Turning now to the first premise, it may be asked whether an offender is simply "obliged" to feel remorse. While it would seem wrong to deny this outright (as if experiencing remorse was in fact supererogatory or, alternatively, always merely permissible), I would suggest that this deontological language does not do full justice to the particular way in which lucid, deep remorse stands as a normative ideal for wrongdoers. It is true enough that one who has wronged another should feel remorse, but one who really does experience remorse fully and deeply is often going beyond others' ordinary "expectations" (predictive and normative). Thus, a kind of hope often accompanies such "expectation", a hope, however, which is not wholly captured by the notion of "going beyond one’s duty”. Moreover, and again this complicates matters, from that remorseful person's point of view it will often strike them that they are simply experiencing "what they must", given what happened. Consider also the common thought that an offender suffering remorse deserves to suffer such pain, as though the remorse itself is a received punishment. Though this thought is slightly misconceived, it does serve to show the complexity of the matter. In short, the nature of remorse's "normative pull” is not reducible without remainder to the language of obligation and its conceptual cognates.

\section{RETRIBUTIVISM AND CULPABILITY}

Bagaric and Amarasekara then turn to examining how the remorse principle may or may not receive support from what they take to be the two main justificatory theories of punishment — utilitarianism and retributivism - and argue that neither supports the remorse principle. That some such doctrinal support is necessary for the principle to stand is made clear but not questioned: "in order for remorse to be justifiable as a sentencing consideration, it must in some way relate to the purpose for punishing offenders in the first place”. ${ }^{11}$

In relation, first, to retributivism, Bagaric and Amarasekara argue that the influential version of retributivism put forward by von Hirsch has no room for remorse. ${ }^{12}$ Von Hirsch's retributivism, they argue, is concerned essentially with imposing

\footnotetext{
${ }^{11} I d$., at 367.

${ }^{12}$ ANDREW VON HiRsCh, CENSURE AND SANCTIONS (1993).
} 
proportional punishment. That is understood by von Hirsch to be a matter of the severity of a penalty being determined by reference to the seriousness of the offence, with the latter, in turn, being a matter of the harmfulness of the offending conduct combined with the extent of the offender's culpability. ${ }^{13}$ Bagaric and Amarasekara argue that remorse, as a post-offence change in the offender, thus does not figure in the equation, ${ }^{14}$ and indeed it seems not to.

However, regardless of the merits of Bagaric and Amarasekara's critique of von Hirsch, it would seem quite possible for a recognisably retributivist sentencer (even one very sympathetic to von Hirsch's approach) to expand the scope of the notion of "culpability" so that it incorporates post-offence matters such as remorse. Culpability, it may be argued, is essentially a matter of blameworthiness, that is of the worthiness or aptness of blaming the offender for what they did. "Blaming" here refers not only to the ascription of agent responsibility but also and primarily to the speech act (subsequent to affixing responsibility) of censuring or reproaching the offender, that is the opposite of praising. Thus an offender's level of blameworthiness need not simply be a measure of the responsibility of the offender for their actions (as a matter of free will, intentionality, level of care taken, etc.) but also a measure of how severely and in what manner they should now be censured for what they did.

Since such censure is to be done at a time after the offence (let us say the offence occurred on January $1^{\text {st }}$ and the time of censure is March $3^{\text {rd }}$ ), the decision must be made as to how to censure the offender on March $3^{\text {rd }}$, which may not be the same as the kind of censure that was appropriate on January $2^{\text {nd }}$. Thus there is room to take into account events that occur after January $1^{\text {st }}$, and indeed after January $2^{\text {nd }}$, but before March $3^{\text {rd }}$ — and the offender's remorse is a prime candidate here. To decide to punish the offender less severely on March $3^{\text {rd }}$ than one would have punished them on January $2^{\text {nd }}$ on the basis of them experiencing remorse after January $2^{\text {nd }}$ is not at all to imply that the offender was any the less responsible for their actions on January $1^{\text {st }}$. It may well be true to say that remorse is irrelevant to the level of responsibility of the offender on January $1^{\text {st }}$, but it need not be irrelevant to the question of their culpability or blameworthiness on March $3^{\text {rd }}$. (This is not yet, of course, to argue that a retributivist ought to take post-offence remorse into account, only that it is consistent for one to do so.) Since a recognisably retributivist approach could take on board post-offence remorse, it would seem that Bagaric and Amarasekara's criticism of von Hirsch's retributivism as a support for remorse as a mitigating factor does not knock out retributivism as such as a possible support for the remorse principle.

\footnotetext{
${ }^{13}$ Id. at 29.

${ }^{14}$ Bagaric \& Amarasekara, supra note 1 , at 367.
} 


\section{COMmUNICATIVE Retributivism}

Bagaric and Amarasekara do indeed go on to consider a different retributivist theory, that of R. A. Duff. They argue that the remorse principle is not supported by Duff's theory, either, despite the fact that remorse plays a central role in it. Bagaric and Amarasekara's argument is that in fact Duff's whole enterprise fails because it cannot justify, in its own "communicative" terms, the hard treatment of offenders, and so any support Duff's theory might be thought to offer the remorse principle will also fail.

In very short compass, Duff's general theory proposes that punishment be conceived as communication of censure to and imposition of (secular) penance upon an offender. He argues that punishment should aim at "the three goals of repentance, reform and reconciliation. These goals are to be pursued by a communicative process of imposing penitential burdens on offenders". ${ }^{15}$ The moral basis of Duff's approach is essentially respect for the offender as both an autonomous human being and a member of our community. That is, we ought to regard an offender as "one of us" and so one with whom we should first try to speak and reason, before we give up and resort merely to forms of self-release (such as revenge) or utilitarian manipulation. Remorse will clearly play a major role in such an approach. The communicative response to - the censuring of — the offender seeks to elicit remorse both as "an appropriate response to the wrong he has done" and as the "intrinsically appropriate way in which those goals [of self-reform and reconciliation] should be pursued". 16

Bagaric and Amarasekara argue that this communicative function cannot in fact warrant the hard treatment that defines punishment. Regardless, however, of whether Bagaric and Amarasekara's general critique of Duff succeeds, it is important to note that Duff himself argues that his account "does not imply that repentance should entitle the offender to a lighter sentence", ${ }^{17}$ as indeed Bagaric and Amarasekara acknowledge, ${ }^{18}$ though referring to Duff's earlier work. ${ }^{19}$ (We can treat remorse and repentance as similar enough for present purposes.) So, it would appear that Duff's general account of punishment does not support the remorse principle in the eyes of either its proponent or its detractors. Bagaric and Amarasekara might argue that Duff is inconsistent here, but, either way, their position seems assured: Duff's approach to sentencing provides no support for the remorse principle. Given this, it would seem that Bagaric and Amarasekara's critique of Duff in their 2001 paper is unnecessary, unless they show, which they do not, how a Duffian approach might, despite Duff's own arguments, argue for the remorse principle. Such an approach I want to outline here: I want to suggest that a commu-

\footnotetext{
${ }^{15}$ DuFf, supra note 3, at 107. This work, which contains Duff's main recent presentation of his approach, was published after Bagaric and Amarasekara, supra note 1, had been accepted for publication.

${ }^{16} \mathrm{Id}$. at 118 .

${ }^{17} \mathrm{Id}$. at 120 .

${ }^{18}$ Bagaric \& Amarasekara, supra note 1 , at 370.

${ }^{19}$ R. A. DUFF, TRIALS AND PUNISHMENTS (1986)
} 
nicative approach can indeed support the remorse principle. I shall outline how by responding to Duff's own arguments against the remorse principle.

In brief, Duff presents two reasons for rejecting the remorse principle. ${ }^{20}$ (Strictly speaking, Duff appears to refer to the stronger view that remorse should mitigate sentence. To deny that proposition is consistent with defending remorse as a permissible mitigating factor. However, Duff's arguments seem to be against the permissive version, too.) First, he endorses the von Hirschian point considered above that the principle of proportionality means that a lessening of the severity of the sentence would imply that the offence was less serious simply because of the post-offence remorse. (He does note, though, that immediate post-offence remorse may in some cases in fact lessen the seriousness of the crime itself.) Secondly, Duff argues that it is mistaken to think there is a distinct repentance-inducing stage of the sentence which should be mitigated in light of its redundancy in the case of the remorseful offender. Duff argues that, from the remorseful offender's point of view, undergoing the punishment serves also to communicate their own repentance, and it is not feasible or appropriate to separate out distinct remorse-inducing and repentance-expressing stages: "the whole sentence serves the dual purpose of inducing and expressing repentance”. ${ }^{21}$

In reply to Duff, I argue as follows. First, as already suggested above, it would seem possible - especially in the context of a communicative approach to sentencing - to broaden the scope of proportionality to include an expanded sense of the blameworthiness of the offender, in which post-offence remorse plays a role. The just punishment is a proportionate censuring address — not just about the offending conduct but also to a human being at a certain stage in the "narrative unfolding" of their life since that conduct. Thus the content of the punishment (what is imposed) should not be identified solely with the referential content of the communicative statement that the punishment is taken to express (for example, "the grave wrong that you did"). It can also express the communicative modulation that can result from awareness of changes in one's interlocutor. This latter aspect makes it more plausible that the act of blaming may be properly influenced by events in the offender's life since the offence. Duff argues, however, that criminal liability should be grounded only in action and not in "character".22 There is an important point here, but perhaps with remorse we can see a blurring of the distinction between conduct and character; and, with the temporal character of communication in mind, it becomes harder to disregard the fuller "character" of the human being we address.

Secondly, a communicative endorsement of the remorse principle does not need to think in terms of "distinct" stages of the punishment for there to be some symbolic value in recognising or acknowledging the value of the offender's remorse by way of mitigation of sentence. Such mitigation is not based on "redundancy", nor is it a "reward". It is, rather, more a matter of acknowledging the remorse and repentance

\footnotetext{
${ }^{20}$ DuFF, supra note 3, at 118-121.

${ }^{21} \mathrm{Id}$. at 121 .

${ }^{22}$ Id. at 215 n. 48.
} 
in a way that symbolizes the kind of acknowledgment we might accord a person whom we (informally) reproach in a purely verbal, non-punitive context - that is, perhaps by lowering our voice, choosing different words, reducing the intensity of the rebuke, pausing and listening to the other person's apology, and so on. If institutional punishment can symbolise verbal censure, it ought also to be able to symbolise modulations of such censure in response to expressed remorse. Of course, such modulation does not necessarily have to take the form of reduction of sentence severity. But such a form of modulation is, it would seem, clearly a possible one and, indeed, one that is likely to be commonly chosen. This also shows why remorse does not require mitigation of sentence to zero: the wrong that was done and suffered still needs to be said. The communicative act is not merely a conveying of information, but also a performative commemoration of the events, a common, shared saying - in which the repentant offender still needs to share, not despite of but because of their repentant understanding of the past.

So much for my Duffian reply to Duff. With regard to Bagaric and Amarasekara's criticisms of Duff's general theory, these are essentially the same as those they level at him in an earlier work. ${ }^{23}$ Duff himself has already replied to those criticisms, ${ }^{24}$ and I shall simply refer the reader to that exchange rather than rehearse it here.

\section{UTILITARIANISM AND REMORSE}

Having dealt with two kinds of retributive theory, Bagaric and Amarasekara go on to argue that utilitarian theories of punishment fare no better in providing support for the remorse principle. They consider, in particular, specific deterrence and rehabilitation, and, again, their argument is that the purported justifications of punishment fail generally and so do not stand so as to provide incidental support for the remorse principle.

\section{A}

Deterrence

In relation to specific deterrence, Bagaric and Amarasekara note that one might expect that since a repentant offender is, presumably, less likely to re-offend, there is a reduced need to deter such an offender by way of punishment. It would be redundant and so parsimony would require that we scale back the punishment appropriately. Bagaric and Amarasekara argue, however, that this argument fails as there is insufficient empirical support for the claim that punishment deters offenders from re-offending.

Whether punishment does specifically deter and, if so, to what extent, are of course difficult questions to answer. However, regardless of the ultimate findings of crimi-

\footnotetext{
${ }^{23}$ Mirko Bagaric and Kumar Amarasekara, The Errors of Retributivism, 24 MELBOURNE U. L. REV. 124 (2000)

${ }^{24}$ R. A. Duff, In Defence of One Type of Retributivism: A Reply to Bagaric and Amarasekara, 24 MELBOURNE U. L. REV. 411 (2000)
} 
nology concerning general behaviour patters, if a judge was faced with a particular case in which they were justifiably confident that this offender would likely be deterred by a particular punishment, then it appears that Bagaric and Amarasekara would, on utilitarian grounds, allow the remorse principle to apply (other conditions being met). However, the further sticking point here, according to Bagaric and Amarasekara, is that neither is there sufficient evidence to show that in general, remorseful offenders re-offend less than non-remorseful offenders. Though this conclusion seems premature, given the limited extent of research in the area, ${ }^{25}$ in any case the same point applies: if our judge was justifiably satisfied that this remorseful offender is less likely to re-offend because of their remorse, then they could mitigate their punishment, following the redundancy rationale. That is, whatever the general behavioural trends, a particular instance is enough to warrant application of the remorse principle to it. General trends and patterns are relevant to "larger" policy matters such as prison funding or the training of welfare officers. But when it comes to proposals to guide (or possibly even constrain) judicial discretion in particular sentencing decisions, scope ought to be preserved for a judge to deal with the "anomalous" particular offender "on their merits" (utilitarian or otherwise). There is no loss of utility in doing so.

One important type of utilitarian approach to punishment that Bagaric and Amarasekara do not consider is that of general deterrence. Is there an argument for the remorse principle that derives from this approach? It might be thought that a "strict" criminal justice system that did not treat remorse as a mitigating factor might prove a more frightening prospect to potential offenders, so that the remorse principle would not find support here. However, it would appear that an argument for the remorse principle can be mounted that addresses the concerns of the general deterrence sentencer, as follows. Given that the remorse principle reflects a widely held view, a failure to put it into practice runs the risk of bringing the criminal justice system into disrepute. Observers in the community may then feel less respect for such a system and in turn this could contribute to greater disobedience of the law. To be sure, this is not a very strong argument, but it does lend some utilitarian weight to the remorse principle.

\section{B \\ Rehabilitation}

Bagaric and Amarasekara note ${ }^{26}$ that, assuming a link between remorse and less recidivism, remorse also seems to make rehabilitative punishment redundant, at least to some degree. However, they argue that rehabilitation and punishment may be inconsistent, insofar as rehabilitative programmes are like beneficial social services, while punishment must, by definition, be painful. If it is true that rehabilitation must stand as an alternative type of sentence to punishment, then offender remorse cannot serve to "mitigate punishment" in the eyes of a pure rehabilitator, since there is no punishment to mitigate.

\footnotetext{
${ }^{25}$ See Proeve et al., supra note 5, at 22-3.

${ }^{26}$ Bagaric \& Amarasekara, supra note 1, at 371.
} 
Let us grant the inconsistency of rehabilitation and punishment. What, then, do we do with a remorseful offender where we seek rehabilitation but eschew punishment as a rehabilitative tool? Such remorse can no longer mitigate punishment, but, from a utilitarian point of view, the redundancy argument is still important: unnecessary rehabilitative programmes would be a waste of the community's resources and the offender's time, and so we should spend no more of either than is needed. Here the concern is with "mitigating" spending and waste rather than punishment, and it includes as much the community's interests as it does the offender's, but the point remains that remorse is still relevant as a mitigating factor in sentencing.

But is imposing pain always inconsistent with rehabilitation? At least sometimes, I would claim, an effective kind of (behavioural) rehabilitation is through an ("inner") reform whereby an offender is censured by way of punishment and experiences shame and remorse (not necessarily always due solely to that censure). From that painful confrontation with their past, some such offenders may then successfully amend their future conduct. If this is possible, then pre-censure remorse would still have an "in principle" role in mitigating the censure. Again, so long as such a scenario is possible, individual judges ought to be free to take remorse into consideration in particular cases where they find the appropriate facts.

There might, however, be a genuinely remorseful offender who lucidly seeks not to have their punishment mitigated, but is prepared, precisely because they are remorseful and repentant, to undertake the full measure of their punishment. This, of course, does not exactly lend weight to the remorse principle. However, whether a sentencing court should accede to such an offender's wish is another matter, since the court is not there simply to grant either victims or offenders what they wish, even if it be reasonable for them to wish it.

\section{FORGIVENESS}

Bagaric and Amarasekara also argue that forgiveness cannot support the remorse principle, essentially because forgiveness, as a private matter involving discretion, relational ties and (usually) minor wrongs, has no role to play in a public criminal justice system. However, it is too bald to say that a public court may never treat a victim's forgiveness of a remorseful offender as a mitigating factor. The law and people's private moral worlds can and do properly intersect, and a public court, even though representing the community rather than the victim, is not obliged never to take a victim's views into account. It can, indeed, be part of its public function of representing the community's collective response to events primarily affecting certain of its individual members that a court in some way take account of victims, whether as angry and hurt or as forgiving. 


\section{Restorative Justice Approaches}

Bagaric and Amarasekara finally look briefly at the role of remorse in restorative justice models. It is not clear whether restorative justice approaches actually have a clear place for a notion such as "mitigation of the normal sentence", for sentencing in the traditional mode is partly what restorative justice has sought to replace or at least to complement by allowing for more varied, negotiated and particularised outcomes. It would seem fairly clear, however, that an offender's remorse has a very important role to play in most restorative justice models, in that they highly value the responsiveness of offenders to what they have done and, indeed, what is happening to them now. ${ }^{27}$ It would seem an odd restorative justice conference that did not positively acknowledge an offender's remorse and somehow lessen the intensity of the "reintegrative shaming" that the conference was partly intended to induce.

Bagaric and Amarasekara suggest that remorse is expected of offenders in restorative justice settings and so is a "necessary but not sufficient pre-condition for the integration of the offender back into society. The pain of recompense and reassurance must yet be met”. ${ }^{28}$ That may be true, but it does not yet tell against the idea that satisfying one of those pre-conditions may partly lessen the overall burden an offender might come to bear through a restorative justice approach. Thus, remorse still seems to retain its mitigating possibilities in this context.

\section{CONCLUSION}

In conclusion, then, Bagaric and Amarasekara's survey of reasons for the remorse principle is not wide enough to enable them to argue that if those purported reasons fail (which, they say, they do), then there is no good reason to accept the remorse principle. (I should note that I have not sought here to make up the gap by providing my own, full survey of what may be said in favour of the remorse principle.) Moreover, most of their arguments against the reasons that they do consider are, at least, controversial. So, even if we granted that the survey was exhaustive, it would be unwise yet to lobby Parliament to prohibit courts from treating offenders' remorse as a mitigating factor when sentencing them.

Perhaps ultimately the remorse principle can be as much a test of an adequate theory of sentencing as it is something that stands in need of a theory's support. That is to say, if one's preferred theory of sentencing cannot accommodate this basic principle, it may be that the theory needs revising and not that the remorse principle needs to be abandoned. ${ }^{29}$

\footnotetext{
${ }^{27}$ See, e.g., Ted Wachtel \& Paul McCold, Restorative Justice In Everyday Life, in ReSTORATIVE JUSTICE AND CIVIL Society 128 (H. Strang \& J. Braithwaite eds., 2001), and Charles K. BARTON, RESTORATIVE JusticE: THE EMPOWERMENT MODEL 135 (2003).

${ }^{28}$ Bagaric \& Amarasekara, supra note 1, at 375.

${ }^{29}$ I would like to thank Professor Bagaric and Professor Duff for their generosity in each commenting on an earlier draft of this article.
} 